\title{
A word with the rich (James 5:1-6) - Part II ${ }^{1}$
}

\author{
O E Alana ${ }^{2}$ \\ (University of Pretoria)
}

\section{ABSTRACT}

\section{A word with the rich (James 5:1-6)}

This second and concluding part of this essay on "A word with the rich", focuses on the social and historical milieu of the Letter of James with a view to appreciating the cultural context giving rise to the apostrophe handed down on the rich by the author of the letter. The texts containing the apostrophe are examined and the challenges they pose to the rich are explored for recommendation to today's rich.

\section{INTRODUCTION}

Having rejected a relative consideration of the problem of wealth and poverty in the Letter of James in the first part of this essay, this second and concluding part attempts to look at the problem from the absolute perspective. This decision is not only informed by the cultural context of the letter, but also by the need to make the message alive in a society that experiences similar exploitation and oppresssion as did the readers of James.

The social and historical milieu of the texts is examined, after which an analysis of the relevant texts is undertaken. The implication of the apostrophe is discussed vis-à-vis the Nigerian society, followed by a conclusion.

\section{SOCIAL HISTORICAL MILIEU}

The question of the social and historical environment of a text is closely related to the identity of the readers to whom the text is

1 Part I of this essay appeared in the previous issue of Verbum et Ecclesia.

2 This paper is published as part of a Post-Doctoral Fellowship programme in the Department of New Testament Studies, Faculty of Theology, University of Pretoria under supervision of Prof $J$ G van der Watt. The financial support of the University is gratefully acknowledged. I should also like to express my gratitude to Professor Stephan Joubert of the Department of New Testament Studies, UP, for the material on the patronage system, that he placed at my disposal. 
addressed. This is because a text does not exist in a vacuum; it is usually related to a person or an object, but in the case of the books of the Bible to an audience. The Sitz im Leben of the Letter of James has been a subject of debate among scholars. The controversy arises over the phrases $\delta \omega \delta \delta \kappa \alpha \phi \nu \lambda \hat{\alpha} \varsigma$ ("twelve tribes") and ' $\epsilon \nu$ ๆ $\delta\llcorner\alpha \sigma \pi о \rho \hat{\alpha}$ ("in Diaspora") at the opening of the letter. If taken literally, the readers are probably Jewish Christians resident in some Roman town or city outside Palestine, like Rome, Alexandria or Corinth as suggested by Laws (1980:25-26) and Martin (1982:12). The conflict between the rich (outsiders) and the poor (insiders) is interpreted as one between competing ideologies. The poor, Jewish believers, are true heirs of the promised kingdom while the salvation of the wealthy, gentile believers, is uncertain (Watson 1997:551). But when viewed metaphorically, the readers could be located in Palestine, as people cut off from social and religious support systems. This latter view receives support in Jewish literature where it is indicated that some Jews referred to as diasporic Jews were sometimes driven from their homeland for political and economic reasons and thus became "aliens" both at home and abroad (Wall 1997:12).

Another view that corroborates the Palestinian audience is that the letter is a perfect reflection of social and political conditions in Judaea at the time of James, the first Bishop of Jerusalem (Bernheim 1997:232). The arguments in favour of Palestinian audience appear more appealing to us, especially as evidenced by the texts and corroborated by the social and historical milieu of the first century Palestine, which the letter is popularly believed to reflect.

The social, cultural, economic and political situations in the Mediterranean societies of the first century CE seem aptly summarised by this statement of Gilmore (1982:192):

I. The Mediterranean societies are all undercapitalized agrarian civilizations. They are characterized by sharp social stratification and by both a relative and absolute scarcity of natural resources...There is little social mobility. Power is highly concentrated in a few hands, and the bureaucratic functions of the state are poorly developed... These conditions are of course ideal for the development of patroniclient ties and a dependency ideology.

Although Gilmore's statement could be a description of the modern world, the general situations have hardly changed from what they 
were in the first century CE Palestine (see Domeris 1993:293). The general situation was that of despondency.

The economy of Palestine of the first century CE was largely agrarian. Clientela or patronage (Joubert 1996:213) or tenancy (Malina 1996:143) was the order of the day. Most of the people were peasants and tenants. The peasants were small-holders who owned small pieces of land and worked on them with their families and perhaps with some hired labourers (as in Mt 13:1-9; Mk 4:1-9; Lk 8:4-8), while the tenants worked the land in proxy for the absentee landlords (as in Lk 16:1-9; Mt 21:33-46; Mk 12:1-12; Lk 20:9-16). There were very wealthy people who provided the mass majority of the peasants who were landless with land and other farming implements including seeds, and these in return worked for a specified share of the harvest (Malina 1996:143). The difference between the two types of farmers is not much; it is in the right of the peasants to dispose of their own income whereas the tenants had no such right. It belonged to their absentee landlords (Moxnes 1988:57). Farmers of both categories most of the time could not live beyond subsistence margin. They were always subject to forces beyond their control such as bad weather, claims from the landlords, the patrons and the state. From the perspective of the Mediterranean people, all goods are limited; hence a person could only increase his or her own supply of them at the expense of someone else (Esler 1994:35). Thus the poor were always at the receiving end. They were also forced, very often, to take loans; such pressure was so intense in the reign of Herod (Stambaugh and Balch 1986:91). The inability to repay could not be validly blamed on bad season; they must pay in full. Where they lacked the means to repay, and that was the case in most of the times, they easily sold themselves into slavery. Thus, profiteering absentee landlords who often were foreigners presented a special problem for the survival of peasants and tenants (Theissen 1978:56). Indeed, patronage was nothing short of "an elite instrument for class domination" (Gilmore 1982:193). These were perhaps the rich being apostrophised in James 5:1-6 for they perfectly fit into that description.

Aside from farming, it has been reported that a considerable volume of trade and commerce was on ground in Palestine of the first century CE (Maynaid-Reid 1981; Jeremias 1969; Stambaugh and Balch 1986). The peace, Pax Romana, which characterised the reign of Augustus, was a catalyst for tourism and commercial activi- 
ties. Good roads, improved modes of travel coupled with effective policing of both sea routes and highways were all in place to make travel relatively safe throughout the Roman Empire (Maynard-Reid 1981:197-199). Even with the unfavourable geographical location of Jerusalem, the city witnessed enterprising trade and commerce, though the pattern of trade was mainly in the form of imports rather than exports (Maynard-Reid 1981:124). Pottery manufacturing centres existed in Galilee and these were a source of local trading between Galilee and the Golan region (Freyne 1996:35-36). Pickled and salted fish was also exported from Galilee to distant places, including Rome. All the gains of the trade and commerce, like the patron-client relations (Moxnes 1991:241), and social values, epitomised by honour and shame went to the rich (Domeris 1993:294).

According to Kahn (1971:1274), the economic situation of Palestine of this period was intolerable due to the "excessive fiscal exploitation by both Herodians and Romans and their corrupt bureaucracies". Different taxes were imposed on the subjects while Roman citizens were exempted. Taxes were levied on the produce of the land, on men, property, sale of animals and all transport of goods across borders. In addition to taxes on the produce of the soil, "head tax" was mandatory on every person (Perkins 1988:31). In addition, the people had to meet many financial commitments to the court of Herod. Perhaps akin to the administrative burden of taxation was the priestly imposed taxes. Jewish males paid half-shekel for support of the Temple. Tithes were also demanded by religious law, to be paid to the priests and Levites (Draper 1992:65, Perkins 1988:31). Added to these pressures was the presence of Roman soldiers. As officers, they could serve as patrons/brokers/middlemen for a village as in Luke 7:1-10. John's charge to soldiers also in Luke 3:14 serves as a marker pointing to the fact that the presence of soldiers could be another form of burden on the people.

The hardship of the poor also appears to have been worsened by the activities of some financiers believed to be Jewish bankers (Furfey 1945:251). The reference to court actions in James 2:6 is probably a reflection of the activities of such bankers against some Christians in the bid to recover debts. Hence the characteristic hostility of James toward the rich who had refused to have pity on the poor. 


\section{CRITICAL ANALYSIS OF TEXTS}

The Letter of James as a document was written to "impress upon Christian Jews how they should prepare in mind and deed for the judgement of the Second Advent" (Adamson 1989:186). The writer employs many figures of speech, mainly aphorisms, to present instructions in respect of practical wisdom and guidance for Christian attitudes and conduct. Thus he deals with issues such as wealth and poverty $(1: 9-11 ; 2: 1-9 ; 4: 13-5: 6)$, faith and wisdom $(1: 2-8)$, testing and tempting (1:12-18), hearing and doing (1:19-27), faith and works $(2: 14-26)$, the Christian and his tongue $(3: 1-18 ; 5: 12)$ among others. The focus of this study is treated in details in three pericopes: 1:9-11;2:1-9 and 4:13-5:6. Generally, the Sitz im Leben is the selfish and rapacious use of wealth among some Christians as among some outsiders. Although the climax of the condemnation is in 5:1-6, for coherence of presentation, I shall follow the arrangement in the letter.

James (1:9-11) starts off his condemnation of the rich with the antithetical parallelism, o $\tau \alpha \pi \epsilon \iota \nu$ ó ("the lowly, the weak") standing

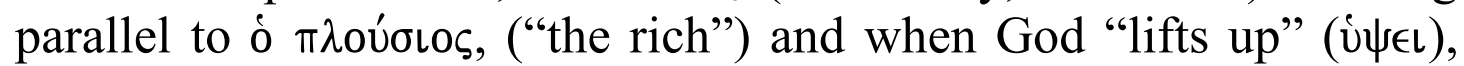
the poor, he "brings down" ( $\tau \alpha \pi \epsilon \iota \nu \omega \sigma \in l)$ the rich (vv.9-10). It is clear from this pericope that those referred to as the rich include Christians. The rich, according to James, will be brought down, not necessarily by loss of property or social status or earthly honour (Maynaid-Reid:144), but in the eschatological judgement that he envisions to be imminent (5:7). James emphasises the worthlessness of earthly riches. He predicts brightening hope for the poor while eternal perdition will be the reward of the earthly rich (Reicke 1964:15). The rich will disappear (REB) or pass away (TEV) like the "flower

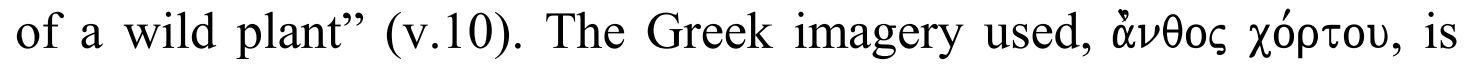
that of the flowers of green herbage, a favourite image of transitoriness in the OT literature (see Job 14:2, Ps 37:2, 90:5-6, 103:15, Is 40:6-8,51:12). It is clear from the OT that when the sun rises, its burning heat entrophies the flower of the field and its beauty affords no protection but perishes with the flower. In the same way, the rich with their dazzling appearance, will fade away "when the sun of the new age, Christ, appears in his effulgent glory" (Reicke1964:16). The aorists used in vv.10 and 11 (both future and present) are, in the words of Moule (1971:12), "to emphasize the suddenness and completeness of the withering", such that depicts the abruptness and finality with which judgement will come upon the rich. James not 
only emphasises the transitoriness of wealth in this pericope, but also exposes the frailty of the rich while the upliftment of the poor is assured (Pretorius 1994:547).

James 2:1-9 provides a sort of theological basis for solidarity with the poor members of the Jacobean community (Boggan 1982: 207). James here continues to demonstrate his concern to and sympathy for the cause of the poor while he resumes his denunciation of the rich with more vehemence. His exhortation here is a condemnation of the practice of partiality, which seems evident in his community but very strangely in favour of the rich at the expense of fellow poor. Partiality as used in this context, means, in the words of Martin (1982:27), "treating those who have power, status, influence, and money with more respect than those who do not, in the hopes of security, favour, and benefits". James' description of the rich man in v. 2 has been a subject of debate among scholars. His fine clothing and gold ring have been interpreted by Reicke (1964:27) to suggest that he was of senatorial rank or a Roman nobleman. His argument is that during the early years of the empire, only such men had the right to a gold ring. His fine garment, according to him, signifies a white toga, such as often worn by politicians. Maynard-Reid (1981:175), however, believes that such appearance was not peculiar to people with the Roman equestrian status, but was commonly worn by rich people in the whole of the Roman world. This latter view is also corroborated by Jeremias (1969:92) who reports that the extravagance of the rich in the whole of the empire was also visible in Jerusalem in their houses, clothing, servants and rich offerings.

What is clear from the picture of the man painted by James is that he was certainly a representative of the aristocracy, a man of honour in the context of the Mediterranean world. He was probably seen as a prospective patron. Hence the preferential treatment accorded him in v. 3, which in James' reckoning is undeserving of an oppresssor. Indeed, the poor were not only discriminating against their fellow poor, but were doing so in favour of the rich. This is seen as an ironical alliance with the class that historically persecuted the impoverished believer and that was tantamount to making the church a tool of persecution or siding with Satan against God (Davids 1982:112). That is a pointer to the fact that believers judged with faulty standards by estimating people according to their material possessions, as rightly put in v. 4 . 
Were there distinctions arrangements regarding seats in James' community such that provoked his position? Distinctions in sitting arrangements were known to have existed within Jewish synagogues (Felder 1982:94). A possible allusion to it is in Mark 12:39 (cf. Lk 20:46) where Jesus describes the Pharisees as those "who choose the reserved seats in the synagogues and the best places at feasts". There is no evidence pointing to such a practice in the community, though it could not be ruled out in view of the Hebrewism (Roberts 1976: 143) or Jewishness of the Jacobean community.

The climax of the pericope comes up in James' declaration of $v$. 5 that the poor is the "elect" of the Kingdom of God. The Greek word used in describing that election, $\mathfrak{\epsilon}^{\prime} \xi \in \lambda^{\prime} \in \xi \alpha \tau 0$, aor. mid. ind., 'є $\kappa \lambda^{\prime} \epsilon \gamma o \mu \alpha \iota$ means "to make a special choice based upon significant preference, often implying a strong favourable attitude toward what is chosen- to choose, choice" (Louw and Nida 1989:30,92). When rendered in the question form (as done in REB), v. 5 is a rhetorical question and is certainly one of the strongest NT statements about the poor, comparing, according to Ward (1969:95), favourably with Lucan and Qumran estimation of the poor. Maynard-Reid (1981: 181) sees James' declaration of the election of the poor as being perfectly in agreement with the tradition of the early church which saw its mission as that to the poor (see Lk 4:18), the chosen of God.

The reference to $\pi \tau \omega \chi o \nu ̀ \varsigma \tau \hat{~} \kappa o ́ \sigma \mu \omega$ ' ("poor people of this world"), is not an attempt to distinguish the poor further or to restrict the idea of the poor. The $\tau \hat{\omega}$ кó $\mu \hat{\omega}$ is a dativus commodi: they are "poor in the view of the world" (Davids 1982:112). The antithesis is thus illustrated by showing that the values of this world are reversed in the world of the kingdom (Hartin 1991:149). Those who are poor in the estimation of the world are now considered to be rich heirs of the kingdom. The striking resemblance between this reference and the first beatitude in $Q$ as used by both Matthew (5:3) and Luke (6:20b) has been noted (see Hartin 1991:149). The Q material reads:

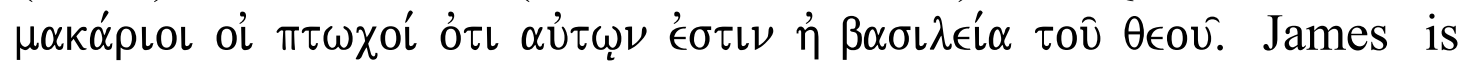
believed to be closer to Luke than to Matthew who has further specified oi $\pi \tau o \chi o i \quad \tau \hat{\omega} \quad \pi \nu \in \dot{u} \mu \alpha \tau \iota$ probably under the influence of Isaiah 61:1. Also while the exact antithesis between the poor and the kingdom is not too obvious in $\mathrm{Q}$, this has been clearly brought out in James formulation. The poor, in the view of the world, is to be considered blessed for they will become rich as heirs of the kingdom. "Poor" is contrasted to "rich" and "world" to the "kingdom". 
The resemblance, no doubt, shows that James, like Matthew and Luke reworked the Jesus' tradition recorded in Q (Hartin 1991:150). It also assists in affirming the Christian character of James' view about the election of the poor (Felder 1982:99). The idea of the poor as the "elect", strictly speaking, is not clearly spelt out in the OT where they are sometimes presented as those to blame for their condition and at other times, provisions are put in place for them as in Exodus 23:6,11, Leviticus 19:9-10 and Deuteronomy 15; 7-11. The OT, however, generally teaches that God has special concern for the poor. It is on the basis of this that God liberated the Israelites from slavery in Egypt (Croatto 1987:51-52). This idea, no doubt, gained prominence in later OT books such as Psalms. It is on the basis of this that scholars, like Dibelius (1976:39-45) have come to the conclusion that it entered the literature of early Judaism through different streams of thought.

It is also evident from the Cynic moralising tradition of the Graeco-Roman world that the cynic philosophers were very critical of the Roman rich for their extravagance and lack of self-control often exhibited in the excessive consumption of luxurious food, wine and other pleasures (Braun 1995:39). The satirical dialogues of the Roman writer Lucian reveal much of the anti-rich stances in the Graeco-Roman societies of antiquity. He was by no means well disposed to the rich. Hence he characterises them in negative terms. For instance, he refers to the rich as those "who plunder and violate and in every way humiliate the poor" (Braun 1995:58-59).

It becomes pertinent to ask the question: why are the rich rejected? The answers are found within the text: they dishonour the poor, oppress the poor, take court actions against the poor and blaspheme against the name of Jesus (vv. 6-7). Reference to legal actions implies that the rich took the poor to courts over issues of debts, rents, wages and unfulfilled pledges (Moffatt 1942:19). The issue of blasphemy against Jesus' holy name in v. 7 rules out a possible suggestion that the rich here are Christians. Maynard-Reid (1981:184-187), however, sees the possibility of James drawing from 1 Enoch 94:8-9: "You have not remembered the Most High in the days of your riches; you have committed blasphemy and unrighteousness".

In vv. 8-9 James makes it clear that anyone who honours the rich at the expense of the poor is not only exhibiting discrimination against those whom God has chosen or merely showing favour to those who oppress the elect of God, but he himself is guilty of blas- 
phemy against God and is a transgressor of the law of God and such a person is in the same category with the murderer and adulterer (Maynard-Reid 1981:186-187). All acts of partiality against the poor are seen by James as a breach of the commandment to love one's neighbour as oneself (see Dt 1:7; 16:19).

The final apostrophe against the rich commences from 4:13-17, though the impression is given in some Bible translations (like TEV) that it belongs to a different pericope from 5:1-6. The two are, however, treated as one in Nestle-Aland's Novum Testamentum Graece (1979) as in other Bible translations (such as REB and NRSV). The tendency to view them as two different pericopes may be due to the fact that different people are apostrophised. In 4:13-17, it is merchants while 5:1-6 has landowners in view. Mayor (1977:153) has this to say in respect of those apostrophised in 5-1-6: "It is no longer the careless worldliness of the bustling trader which is condemned, but the more deadly worldliness of the unjust capitalist or landlord". Difference needs not be drawn between the rich merchants, the rich landowners and even the rich bankers. In most cases, the same person combined the three works (Maynard-Reid 1981:182) and in any case, all the three belonged to the rich class. Both sections have identical mode of introduction, beginning with 'A $\gamma \epsilon \nu \hat{v} \nu$, ("come now"). Moreover, oi $\lambda \in \gamma o \nu \tau \epsilon \varsigma$ of $4: 13$ is cast in the same mode as

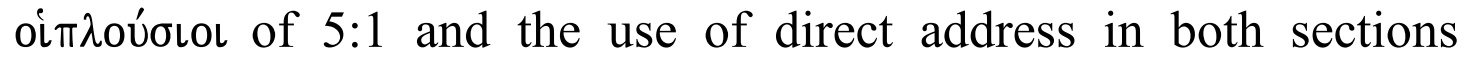
attests to the fact that both exhibit parallel ideas (Felder 1982:150; Dibelius 1976:230-231; Davids 1982:171).

The charge against the commercial schemers (Reicke 1964:48) is that they are braggarts. They do not trust God again, but rely on their own devices (Malina 1993:105). They do not concede any position to God and thus do not seem to have reckoned with the wisdom in "no one knows what tomorrow will bring" (as stated in $\operatorname{Pr} 27: 1$ ). Hence the condemnation. The rich here are compared to $\dot{\alpha} \tau \mu \mathrm{s} \varsigma$, ["vapor, steam, smoke"] (Rienecke 1976:738). An important connotation in the use of this word is the fact that it disappears so readily and it has been compared to the steam rising from a boiling pot (Louw and Nida 1989, 1:36). This imagery graphically depicts the transience of the human life. The possible influence of Jesus' parable of the rich fool in Luke 12:16-20 on James here is very likely. Its analogies are to be found in both Jewish and Graeco-Roman milieus against senseless speculators in their search for riches. Ben Sira (11:19) has this to say: 
What time he said: "I have found rest,

And now I will enjoy my goods...

He knoweth not what lot shall befall;

He shall leave (them) to others and die".

Concerning a Roman knight called Cornelius Senecio, Seneca a Roman philosopher has this to says: "... he who was venturing investment by land and sea, who had entered public life and left no type of business untried, during the very realization of financial success and during the very onrush of the money that flowed into his coffers, was snatched from the world [by death]!" (see MaynardReid 1981:219-220). All such planning without God is self-righteousness; it is nothing but emptiness.

In 5:1-6, James descends heavily on the rich. He insists that judgement and condemnation are inevitable on them. Vv. 1-3 consists of pronouncement of judgement while vv. 4-6 deal with the charges, which lead to such a judgement (Adamson 1976:185-187; Laws 1980:201-207; Bauckham 1999:57). James in 5:1-6, like in 4:13-17, employs rhetorically direct address in the style of the OT prophetic judgement oracle and Jesus' oracle of judgement (Bauckham 1999:57). Adamson (1976:12) is of the view that the condemnation is probably meant to placate the oppressed that could be solaced by the threat of imminent divine judgement on their oppresssors. I think that the mood of James is far more serious than that. He means the actual visiting of the wrath of God on the oppressive rich. To see 5:1-6 as no more than an attempt to placate the poor is to reduce the whole condemnation to a mere social function. As far as James is concerned, there is no hope for the rich but judgement and relegation of status. They are to cry ( $\kappa \lambda \alpha u ́ \sigma \alpha \tau \epsilon)$ and howl

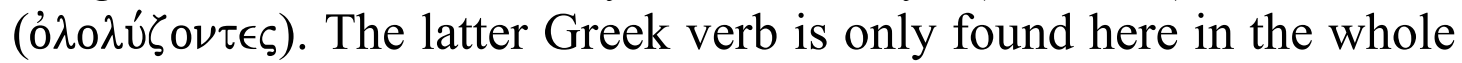
of the NT and is in the LXX used as the expression of violent grief (Rienecker 1976:739).

The condemnation of the rich as sinners and the idea that their riches and possessions will perish are also found in 1 Enoch 94:9; 97:8-10. Parallels are as well found in Revelation 3:17 in respect of Laodicean Christians who are made wretched, pitiable, poor, blind and naked by riches (Wall 1997:227). The images of rotting away, moth eating and corrosion or rusting all point to the vanity of earthly riches. Hartin (1991:179-181) has pointed to the similarities in thought and vocabulary between James 5:1-6 and Matthew 6:19-21 and Luke 12:33-34, tracing them to common use of Q. The wisdom 
literature, too, is aware of similar thoughts and expressions as evidenced by Ben Sira 42:13; 29:9-12 where the images of moth-eaten garments and wealth and money rusting are found (Hartin 1991:180).

The impending doom of the rich is caused by their exploitation of the poor whose wages they fail to pay. Such a behaviour is against the Mosaic laws: "[d]o not hold back the wages of someone you have hired, not even for one night" (Lv 19:13b). Intertestamental literature such as Tobit 4:14 and 1 Enoch 96:5, as well as rabbinic literature all re-echoe the Levitical injunction denouncing failure in paying a labourer his wages (Maynaid-Reid 1981:226,229). The rich are also guilty of luxurious living with no concern for the poor they are exploiting (v. 5). James, like the sage Ben Sira (34:22), equates the behaviour of the rich with murder (v. 6). Hence the blood of the righteous workers is crying for vengeance like the blood of Abel $(\mathrm{Gn}$ 4:10). That judgement is at hand to bring about the ultimate reversal of status - the lowly will be exalted while the rich will be brought low. As for the rich, their evil inclination has blindfolded them into ignoring the judgement that is coming upon them (Marcus 1982: 621). The perfect tenses employed by James to describe the state of the rich, according to Dibelius (1976:236), are of prophetic anticipation of judgement. It is doubtful whether one can find in them, as Easton (1957:63) and Hamann (1980:71) have suggested an indication of the present reality of divine judgement. James does not leave room for hope of forgiveness for the rich as he, like other earliest Christians, expects an imminent Parousia.; he does not demand any justice for the poor (Moffatt 1942:67-68). His consolation is that their exaltation is so imminent; they only need to be patient (v. 7).

In view of James' hard position against the rich and earthly wealth, it becomes germane to ask: what then should be Christian attitude to wealth? James gives some hints on how Christians are to make judicious use of wealth. Like Jesus gives approval to Zacchaeus' use of his wealth for charity and restitution (Nkpong 1996: 206), James expects the rich to assist the poor whom he identifies as "orphans and widows in their suffering" (1:27). Even in 2:15-16 James discusses "justification by work" within the context of the rich assisting the needy. A wealthy Christian, as far as James is concerned, must redistribute his wealth through charity and assistance to the poor. Despite the fact that wealth is seen as being inherently evil and capable of leading people astray, James offers wealthy Chris- 
tians the challenge in the words of Kelly (1967:2290), "to so make use of their wealth that what would normally be an obstacle to holiness becomes the means of obtaining that holiness".

\section{IMPLICATION FOR CHRISTIANS IN NIGERIA}

The textual and milieu analyses above make it clear that James' displeasure was directed against all categories of the rich of his days for their ostentatious living and wicked oppression of the poor. He did not protect the rich so that they could be his patrons. Rather, he elected to protect and solace the poor who had been so culturally, socially and economically degraded by the rich. The liberation of the poor was his chief concern. That was the tradition he inherited from Jesus whose salvific message is addressed preferentially (Croatto 1987:53) to the poor. It is the projection, which Jesus himself takes over from the OT to which the liberation of the poor is central. All later Jewish traditions, like the OT, anathematise riches accumulated at the expense of the poor or greedily and selfishly used.

The current situation in which the rich of our time are behaving like the rich of James' days calls for sober reflection. The rich characteristically use their social and economic influences, which were acquired greedily at the expense of the poor in the first instance, to humiliate the poor. This is even evident in the church today where it appears some clergy not only condone but also indeed abet such behaviour just because of the patronage they enjoy from the rich. The contributions of the poor are no more appreciated in the church today. It is the wealthy that are "begged" with church chieftaincy titles just for the sake of their money even when it is a common knowledge that most of them are morally and spiritually bankrupt. The story of the widow's mite (Lk 21:1-4; Mk 12:41-44) has, literally speaking, been expunged from the NT; it is no longer fashionable as a paradigm of selfless service to use in the church (Alana 1990:197). More fashionable paradigms are now found in fantastic stories of prosperity ministry. Christians who must prosper now have to "offer generously" so that they could be "blessed abundantly". The news of such offering is heavily publicised as a motivation for prospective donors/givers. The poor who have nothing extraordinary to offer have nothing tangible, if anything at all, to receive as blessing. They may as well stay in their homes. Jesus' gospel for the poor has been reversed. It is now the gospel for the rich. What a reversal of reversal! This hard time for the poor is perhaps not pecu- 
liar to Nigeria. I seem to have support in Tidball (1983:78-79) who attests to social discriminations in the church in the western world as well.

The abandonment of Jesus' original gospel for the liberation of the poor by many a church leader today accounts for the unholy relationship between them and some tyrannical rulers whose governments have worsened the lots of the common people. A case in mind is the way some church leaders were rushing to Abuja, Nigeria's new capital, to visit and pray for General I B Babangida in the guise of praying for the stability of the country after his annulment of a Presidential election that cost the country a fortune in 1993. Some of the clergy could not resist the lust for money, as it was the practice of the tyrants to give those august visitors large sums of money. Here are Christian leaders abetting the callousness perpetrated on the generality of the people. It should be remembered that those brutes were not Christians. And the "responsibility" fell on some Christian leaders to "prop" up such discredited regimes with prayers. James' denunciation of the rapacious rich of his days is a challenge to Christians to have a rethink and strive for individual and corporate moral renewal that will ultimately lead to a change of social value. It is time all such Christian leaders began to make amends.

James' mind cannot be individualised in terms of individual rich people from the developed rich countries sending relief materials to the poor in developing countries as done by Hamann (1980:73). That reading cannot be acceptable to theologians from developing countries. After all, hermeneutics, according to Croatto (1987:69-70), is concerned with updating and actualising biblical messages with a view to rending the biblical kerygma effectively for our present day situations; the message of the Bible must not only be updated but has to be recreated. Poverty and wealth cannot be discussed without relating it to the economic adventures of the developed countries vis-àvis their manipulation of the world economic system to the disadvantage of the poor nations. This is done through the instrumentality of the World Bank vis-à-vis the International Monetary Fund.

These institutions have in the guise of economic reforms through the faceless Economic Structural Adjustment Program (ESAP) crippled the economies of many Third-World countries that have tried it. As soon as it was introduced in Nigeria in 1987, the hitherto tottering economy swiftly crumbled. It is all an effort to maintain their economic lead while the poor countries remain where 
they are (Alana 1990:197). The wealth of the poor nations are stolen by heartless leaders while in power and kept in Western Banks. The loots of the Nigerian military juntas are still being recovered uneasily, though with the belated assistance of some western countries whose unfair economic systems made it possible to bank such stolen monies in the first instance. The apostrophe of "James the Wise" critiques such economic systems.

The church as the body of Christ must not be associated with social distinctions and economic gangsterism called capitalism. Draper (1993:67) is very correct when he says: "Whatever the virtues or vices of capitalism as an economic systems, it must not be associated with 'Christian civilization'". All the confrontations of Jesus with the elite class (and their representatives) of his days which culminated in his crucifixion were in the direction of reversing the status quo. For Christians to now work towards the reversal of the work of Jesus is not only a reversal of the great reversal but an overt participation in the crucifixion of Jesus.

\section{CONCLUSION}

Christians are reminded of the original levelling principle of Christianity, which Jesus achieved through the reversal of the status quo of his days, the price of which he paid with his life. They are also reminded of the fact that true belief must not give room for social distinctions, more so against the poor, whom the NT proclaims the apparent heirs of the eschatological reign of God. Although wealth is inherently evil, it is clear that the NT shows the way it could be accommodated in the new commonwealth inaugurated by Jesus. It is, according to Moxnes (1988:167), when wealth becomes an end in itself, and no more a means to be used for common needs, that it becomes demonic and a threat to human existence. Restitution and charity are ways by which wealth can be properly utilised.

On the whole, redistribution of wealth must be pursued in such a way that some people or nations should not be keeping excess while others are in abject want. The weakness of the poor is sometimes not entirely caused by them but by some selfish and mischievous machinations of the powerful rich. In the words of Malina (1987:366), 'Jesus' injunction to give one's goods to the poor is not about self-impoverishment but about redistribution of wealth; and motives for giving to the poor are not rooted in self-satisfying charity but in God-ordained, socially-required restitution". 


\section{Consulted literature}

Adamson, J B 1976. The Epistle of James. Grand Rapids: Eerdmans (The New International Commentary on the New Testament).

Alana, O E 1990. Reconsidering the poor by gospel norms, AFER: African Ecclesial Review 32/4:193-200.

Bauckham, R 1999. James. London: Routledge, (New Testament Readings).

Bernheim, P-A 1997. James, the brother of Jesus. (Translated by John Bowden from French). London: SCM.

Boggan, C W 1982. Wealth in the Epistle of James. Unpublished Ph.D.-Dissertation: Southern Baptist Seminary.

Braun, W 1995. Feasting and social rhetoric in Luke 14. Cambridge: Cambridge University Press, (Society for New Testament Studies Monograph Series 85).

Croatto, J S 1987. Biblical Hermeneutics. (Translated by Robert R Barr from the Spanish). New York: Orbis Books.

Davids, P H 1982. The Epistle of James. A Commentary on the Greek Text. Exeter: The Paternoster (The New International Greek Testament Commentary).

Dibelius, M 1976. James. Philadelphia: Fortress (Hermeneia Series).

Domeris, W R 1993. Honour and shame in the New Testament, Neotestamentica 27/2:283-297.

Draper, J A 1992. “Go sell all that you have..." (Mark 10:17-30), Journal of Theology for South Africa 79:63-69.

Easton, B S 1957. The Epistle of James: introduction and exegesis, in The Interpreter's Bible 12, 3-74. New York: Abingdon.

Esler, P H 1994. The first Christians in their social worlds. social scientific approaches to New Testament Interpretation. London \& New York: Routledge.

-, 1996. Modelling early Christianity. Social-Scientific studies of New Testament in context, 23-46. London \& New York: Routledge.

Felder, C H 1982. Wisdom, Law and Social Concern in the Epistle of James. Unpublished Ph.D.-Dissertation, Columbia University.

Freyne, S 1996. Herodian Economics in Galilee, in Esler P F (ed.), Modelling early Christianity. Social-Scientific studies of New Testament in context, 2346. London \& New York: Routledge.

Furfey, P H 1945. The rich and cognates in the New Testament, $C B Q$ 5:245263.

Gilmore, D D 1982. Anthropology of the Mediterranean Area, ANA 11:175205. 
Hamann, H P 1980. James. Adelaide: Lutheran (Jude Chi-Rho Commentary).

Hartin, P J 1991. James and the Q sayings of Jesus. Sheffield: JSOT.

Jeremias, J 1969. Jerusalem in the time of Jesus. An investigation into economic and social conditions during the New Testament period (Translated by Cave, F H and C H from German). London: SCM.

Joubert, S J 1996. Modelling early Christianity. Social-Scientific studies of New Testament in context, 23-46. London \& New York: Routledge.

-, 1996. Managing the Household: Paul as Paterfamilias of the Christian household group in Corinth, in Esler 1996:213-223.

Kahn, A 1971. Economic History, in Encyclopedia Judaica 16:1266-1324.

Kelly, J 1967. The biblical meaning of poverty and riches, TBT 33:2282-90.

Laws, S 1980. A commentary on the epistle of James. London: A. \& C Black (Black's New Testament Commentaries).

Louw, J P \& Nida, E A 1989. Greek-English Lexicon of the New Testament based on semantic domains 1 \& 2. Cape Town: Bible Society of South Africa.

Malina, B J 1987. Wealth and poverty in the New Testament, Int 41/4:354-367.

-, 1993. The New Testament world: insights from cultural anthropology. Rev. ed. Louisville, Kentucky: Westminster/John Knox.

-, 1996. The social world of Jesus and the gospels. London \& New York: Routledge.

Marcus, J 1982. The evil inclination in James, $C B Q$ 44: 606-621.

Martin, R A 1982. James. Minnesota: Augsbury (Augsburg Commentary on the New Testament).

Maynard-Reid, P U 1981. Poor and Rich in the Epistle of James: A socio-historical and exegetical study. Unpublished D.Th.-Dissertation: Andrews University.

Mayor, J B 1977. The epistle of James: the Greek text with introduction, notes, comments. Minnesota: Klock \& Klock.

Moffatt, J 1942. The general epistle: James, Peter, and Judes. New York: Harper \& Row (The Moffatt New Testament commentary).

Moule, C D F 1971. An idiom book of New Testament Greek. Cambridge: Cambridge University Press.

Moxnes, Halvor 1988. The economy of the kingdom. Social conflict and economic relations in Luke's Gospel. Philadelphia: Fortress.

-, 1991. Patron-Client relations and the new community in Luke-Acts, in Neyrey, J H (ed.), The social world of Luke-Acts: models for interpretation. Peabody, MA: Hendrickson. 
(Nestle-Aland), ${ }^{26}$ 1976. Novum Testamentum Graece, Stuttgart Deutsche Bibelstiftung.

Nkpong, J S 1996. The parable of the shrewd manager (Luke 16:1-13): an essay in inculturation Biblical hermeneutic, Semeia 73:189-210.

Perkins, P 1988. Reading the New Testament. London: Geoffrey Chapman.

Pretorius, E A C 1994. Coherency in James: A soteriological intent? Neotestamentica 28/2:541-555.

Reicke, B O 1964. The Epistle of James, Peter and Jude, in The Anchor Bible 37, New York: Doubleday.

Rienecker, F 1976. A linguistic key to the Greek New Testament. Michigan: Zondervan Corporation.

Roberts, R R 1976. Studies in James. Indiana: BMH books.

Stambaugh, J E \& Balch, D L 1986. The New Testament in its social environment. Philadelphia: Westminster.

Theissen, G 1977. Sociology of early Palestinian Christianity. Philadelphia: Fortress.

Tidball, D 1983. An introduction to the sociology of the New Testament. Exeter: Paternoster.

Wall, R W 1997. Community of the wise: the letter of James. Valley Forge, Pennsylvania: Trinity.

Ward, R B 1969. Partiality in the Assembly, HTR 62:87-97.

Watson, D F 1997. James, Letter of, in Martin R P \& Davids P H (eds.), Dictionary of the later New Testament and its developments. England: InterVarsity Press. 